\title{
Kinetics of chalcopyrite leaching in either ferric sulphate or cupric sulphate media in the presence of $\mathrm{NaCl}$
}

\author{
Tacia C. Veloso ${ }^{\text {a }}$, Johne J.M. Peixoto ${ }^{\mathrm{b}}$, Márcio S. Pereira ${ }^{\mathrm{b}}$, Versiane A. Leao ${ }^{\mathrm{c}, *}$ \\ a Graduate Program in Materials Engineering, Brazil \\ b Universidade Federal de Ouro Preto, Brazil \\ c Department of Metallurgical and Materials Engineering, Brazil
}

\section{A R T I C L E I N F O}

\section{Article history:}

Received 10 May 2015

Received in revised form 30 December 2015

Accepted 22 January 2016

Available online 23 January 2016

\section{Keywords:}

Chalcopyrite

Chloride leaching

Activation energy

Shrinking core model

Particle size distribution

\begin{abstract}
A B S T R A C T
The shrinking core model (SCM) has been extensively applied in the kinetics analysis of particulate systems. This is because in its classical form it is one of the simplest models developed for fluid-solid reactions. However, it requires single-sized solid grains failing to describe the leaching kinetics for broad particle size distributions (PSDs). The current investigation successfully applied an extension of the SCM to the leaching of chalcopyrite with a broad PSD in a mixed chloride-sulphate solution. Such a medium was selected because there is renewed attention to leaching in mixed systems due to the increasing utilization of saline waters in both leaching and bioleaching of sulphide ores. Moreover, chloride is a catalyst of chalcopyrite leaching. Specifically, the effects of temperature $\left(70{ }^{\circ} \mathrm{C}\right.$ to $\left.90{ }^{\circ} \mathrm{C}\right)$ and reagent $\left(\mathrm{Fe}^{3+}, \mathrm{Cu}^{2+}\right.$ and $\left.\mathrm{Cl}^{-}\right)$concentrations on the leaching kinetics were determined. The results showed that chalcopyrite leaching was faster with $\mathrm{Cu}^{2+}$ (larger rate constant) than with $\mathrm{Fe}^{3+}$, but the activation energy was similar in both cases with $66.6 \mathrm{~kJ} / \mathrm{mol}$ for $0.5 \mathrm{~mol} / \mathrm{L}$ of $\mathrm{Cu}^{2+}$ and $66.8 \mathrm{~kJ} / \mathrm{mol}$ with $1.0 \mathrm{~mol} / \mathrm{L} \mathrm{Fe}^{3+}$.
\end{abstract}

(C) 2016 Elsevier B.V. All rights reserved.

\section{Introduction}

Chalcopyrite $\left(\mathrm{CuFeS}_{2}\right)$ is the most abundant copper mineral, comprising roughly $70 \%$ of the world reserves, therefore its relevance to the copper industry is evident (Kaplun et al., 2011). Such a mineral is also a very stable copper sulphide, and is refractory with regards to hydrometallurgical processing. For this reason, chalcopyrite leaching is slower as compared to that of other copper sulphides such as chalcocite $\left(\mathrm{Cu}_{2} \mathrm{~S}\right)$ and bornite $\left(\mathrm{Cu}_{5} \mathrm{FeS}_{4}\right)$. Thus, numerous studies have been carried out seeking to determine the various parameters that influence its leaching kinetics, such as temperature, particle size, stirring rate, and solution type (Yévenes et al., 2010b).

Hydrometallurgical processes developed to treat chalcopyrite ores and/or concentrates can be classified as nitrate, chloride, sulphate or ammonia leaching with respect to the applied leaching solution. Regardless of the selected leaching agent the presence of an oxidant such as ferric iron, cupric ions or oxygen is always required to oxide the sulphide and release copper. Notwithstanding, sulphate-based leaching has some advantages over other leaching media because sulphate leaching is generally simpler and better understood and the recovery of copper by solvent extraction-electrolysis is relatively

\footnotetext{
* Corresponding author at: Bio \& Hydrometallurgy Laboratory Department of Metallurgical and Materials Engg. Universidade Federal de Ouro Preto Campus Morro do Cruzeiro, s.n. 35400-000 Ouro Preto, MG, Brazil. Tel.: +55 3135591102.

E-mail addresses: taciaveloso@yahoo.com.br (T.C. Veloso), johnepeix@yahoo.com.br (J.J.M. Peixoto), versiane@demet.em.ufop.br (V.A. Leao).
}

straightforward. However, there is a critical shortcoming: the leaching kinetics of chalcopyrite is slow in ferric sulphate systems (Hackl et al., 1995). One way of circumventing this problem, which has been extensively investigated, is the addition of chloride ions to the sulphate medium (Ruiz et al., 2011). This is because the presence of chloride ions reduces chalcopyrite passivation and stabilizes $\mathrm{Cu}(\mathrm{I})$ ion in solution, adding a second redox couple to the system, thus facilitating copper extraction (Carneiro and Leão, 2007; Watling, 2013).

The mechanisms proposed for the dissolution of chalcopyrite in both sulphate and chloride media are still very controversial and several alternative mechanisms have been suggested. The oxidative dissolution of chalcopyrite in acid ferric or cupric solutions can be described by the mixed-potential electrochemical model and the following anodic reaction is proposed ((1)) (Nicol et al., 2010):

$\mathrm{CuFeS}_{2}(\mathrm{~s})=\mathrm{Cu}^{2+}(\mathrm{aq})+\mathrm{Fe}^{2+}(\mathrm{aq})+\mathrm{S}^{0}(\mathrm{~s})+4 \mathrm{e} \quad \mathrm{E}^{\circ}=0.425 \mathrm{~V}($ vs SHE$)$

Eq. 1 is coupled to the cathodic reactions (2 or 3) (Yoo et al., 2010): $4 \mathrm{Fe}^{3+}(\mathrm{aq})+4 \mathrm{e}=4 \mathrm{Fe}^{2+}(\mathrm{aq}) \quad \mathrm{E}^{\circ}=0.77 \mathrm{~V} \quad($ vs SHE $)$

and/or

$4 \mathrm{CuCl}_{2}{ }^{0}(\mathrm{aq})+4 \mathrm{Cl}^{-}(\mathrm{aq})+4 \mathrm{e}=4 \mathrm{CuCl}_{3}{ }^{2-}(\mathrm{aq}) \quad \mathrm{E}^{\circ}=0.54 \mathrm{~V} \quad$ (vs SHE) 
Elemental sulphur has been commonly detected as a product of chalcopyrite dissolution, but the formation of metal-deficient sulphides in acidic media has also been suggested. The formation of intermediate non-stoichiometric phases is represented by (4), where y is larger than x (Warren et al., 1982; Majuste et al., 2012):

$$
\begin{aligned}
\mathrm{CuFeS}_{2}(\mathrm{~s})= & \mathrm{Cu}_{(1-\mathrm{x})} \mathrm{Fe}_{(1-\mathrm{y})} \mathrm{S}_{(2-\mathrm{z})}(\mathrm{s})+\mathrm{xCu}^{2+}(\mathrm{aq})+\mathrm{yFe}^{2+}(\mathrm{aq}) \\
& +\mathrm{zS}^{0}(\mathrm{~s})+2(\mathrm{x}+\mathrm{y}) \mathrm{e}
\end{aligned}
$$

The non-stoichiometric phase presented in (4) would be oxidized to covellite (CuS) and, subsequently, to elemental sulphur (S), through consecutive reactions ((5) and (6)) or, then, directly ((7)) (Warren et al., 1982; Majuste et al., 2012).

$$
\begin{aligned}
\mathrm{Cu}_{(1-x)} \mathrm{Fe}_{(1-y)} \mathrm{S}_{(2-z)}(\mathrm{s})= & (2-z) \mathrm{CuS}(\mathrm{s})+(-1-\mathrm{x}+\mathrm{z}) \mathrm{Cu}^{2+}(\mathrm{aq}) \\
& +(1-\mathrm{y}) \mathrm{Fe}^{2+}(\mathrm{aq})+2(-\mathrm{x}-\mathrm{y}+\mathrm{z}) \mathrm{e}
\end{aligned}
$$

$\mathrm{CuS}(\mathrm{s})=\mathrm{Cu}^{2+} \mathrm{S}^{0}(\mathrm{~s})+2 \mathrm{e}$

$\mathrm{Cu}_{(1-x)} \mathrm{Fe}_{(1-\mathrm{y})} \mathrm{S}_{(2-\mathrm{z})}(\mathrm{s})=(1+\mathrm{x}) \mathrm{Cu}^{2+}(\mathrm{aq})+(1-\mathrm{y}) \mathrm{Fe}^{2+}(\mathrm{aq})$

$$
+(2-z) S^{0}(s)+2(2-x-y) e
$$

Covellite (CuS) was positively detected on mineral particles after leaching in chloride (Yévenes et al., 2010b) and sulphate (Córdoba et al., 2008b) solutions whereas bornite $\left(\mathrm{Cu}_{5} \mathrm{FeS}_{4}\right)$ has been cited as an intermediate phase (Majuste et al., 2012).

Copper leaching in chloride systems has been investigated for quite some time (Watling, 2014). However, no industrial process has been implemented, mostly likely because of the corrosion problems related to chloride leaching. The CESL process utilizes chloride ions to catalyse chalcopyrite oxidation (by oxygen) to copper sulphate, but it did not result in a commercial process so far despite being already trialled in a demonstration scale (Sahu and Asselin, 2011). Nevertheless, the major mining companies have patents covering chloride leaching (Nicol et al., 2012; Ohtsuka and Mitarai, 2008; Rautenbach et al., 2011) and with the increasingly stringent regulations on water usage in many countries, saline water and seawater are becoming a real option for hydrometallurgical operations as for example, in BatuHijau (Indonesia), BHP Nickel (Australia), Lipesed, Michilla, Esperanza, Algorta Norte, Mantos de la Luna and Las Luces (Chile), which are using raw seawater in their processes (Torres et al., 2015). That explains the renewed interest in chloride leaching. Notwithstanding, many scientific aspects of the combined sulphate-chloride leaching are still not well understood despite its technological importance.

The shrinking core model (SCM) (Levenspiel, 1999) is one of the simplest models developed for fluid-solid reactions and has been extensively applied in the kinetics analysis of particulate systems. Its traditional form assumes an isothermal nth-order irreversible kinetics and a pseudo-steady state (PSS) approximation, which implies in a constant concentration of the dissolved reagent. Moreover, the model was developed for particles the same size (single-sized particles) in its classical form. There were many attempts of extending the SCM to conditions more complex than those originally described by Levenspiel (1999), but the classical form remains largely used in hydrometallurgy. Nevertheless, many leaching kinetics studies are performed with broad particle size distributions (PSDs), particularly when ultrafine milling is applied, which violates the assumptions of the classical SCM. Incorporating the effect of PSD in the kinetics analysis of fluid-solid reaction systems was proposed subsequently to the original development of the SCM (Murhammer et al., 1986) and one of the simplest mathematical models incorporating such effects was proposed by Gbor and Jia (2004).

Examples of the SCM application to model chalcopyrite leaching comprise the following systems: (i) hydrogen peroxide (Antonijević et al., 2004), (ii) chloride media (Baba et al., 2013) and (iii) the leaching kinetics of covellite produced from the reaction between chalcopyrite and gaseous sulphur (Padilla et al., 2013). Nevertheless, some inconsistencies can be found in the scientific literature, particularly in terms of the rate-determining step (Nicol et al., 2010). Some researchers proposed that chalcopyrite leaching is a chemical controlled process (Córdoba et al., 2008b; Hirato et al., 1987; Kaplun et al., 2011; Ruiz et al., 2011); whereas others reported a diffusion-controlled mechanism (Bonan et al., 1981; Carneiro and Leão, 2007; Córdoba et al., 2008c). Therefore, the activation energy vary broadly with values between $38 \mathrm{~kJ} / \mathrm{mol}$ and $130 \mathrm{~kJ} / \mathrm{mol}$ proposed for ferric sulphate leaching in the $35^{\circ} \mathrm{C}-100{ }^{\circ} \mathrm{C}$ temperature range (Dutrizac, 1981). Another source of inconsistencies is the type of experiment selected. Some works were performed with particulate systems (Al-Harahsheh et al., 2008; Bonan et al., 1981; Córdoba et al., 2008b; Dutrizac, 1981; Havlík and Kammel, 1995; Lu et al., 2000; Yoo et al., 2010) whereas other investigated the leaching kinetics of massive chalcopyrite samples (Cai et al., 2012; Palmer et al., 1981) or applied rotating disc techniques to synthetic and natural chalcopyrite (Dutrizac, 1978; Hirato et al., 1987). Also, kinetics analysis using electrochemical data can be usually found (Lundström et al., 2005; Majima et al., 1985; Majuste et al., 2012). In addition, some works did not have a detailed description of the mineral features (Watling, 2013).

Therefore, the current work investigated the leaching kinetics of a chalcopyrite sample, taking into account the effect of the particle size distribution (PSD) through the Gbor and Jia (2004) approach to the SCM. Particularly, the effects of temperature and type of oxidant (either ferric or cupric ions) on the dissolution rate of chalcopyrite in combined sulphate chloride media were investigated.

\section{The effect of PSD on the SCM}

Gbor and Jia (2004) incorporated the effect of PSD into the SCM for each of the possible kinetic controls developed for shrinking core particles of constant size: (i) chemical reaction-control; (ii) ash layer diffusion-control and (iii) film-diffusion control. According to the authors, for mono-sized particles of diameter $D$, undergoing a shrinking core form of dissolution, the fraction unconverted is a function of particle size and time $((8))$.

$$
1-X_{B}=f(D, t)
$$

where $\mathrm{X}_{\mathrm{B}}=$ fraction of $\mathrm{B}$ in solid that is converted to products.

For a chemically-controlled process, the fraction unconverted $\left(1-X_{B}\right)$ as function of diameter (D) and time ( $t$ ) is represented by (9).

$f(D, t)=1-X_{B}=\left(1-\frac{k_{r n} t}{D}\right)^{3}$

where $k_{r n}=k_{r} D$, and is independent of particle size since $k_{r}$ (rate constant for chemical control) is inversely proportional to $\mathrm{D}$ (or R).

For an ash/inert layer diffusion-controlled process, no algebraic expression can be obtained for $f(D, t)$. The value of $f(D, t)$ has to be determined for each $\mathrm{D}$, using (10).

$1-3\left(1-X_{B}\right)^{\frac{2}{3}}+2\left(1-X_{B}\right)=k_{d n} t / D^{2}$

where $\mathrm{k}_{\mathrm{dn}}=\mathrm{k}_{\mathrm{d}} \mathrm{D}^{2}$, and is independent of particle size since $\mathrm{k}_{\mathrm{d}}$ (rate constant for ash layer diffusion control) is inversely proportional to $\mathrm{D}^{2}$ (or $\mathrm{R}^{2}$ ).

Finally, for a liquid film-diffusion controlled process:

$f(D, t)=1-X_{B}=\left(\frac{k_{m n} t}{D}\right)$

where $\mathrm{k}_{\mathrm{mn}}=\mathrm{k}_{\mathrm{m}} \mathrm{D}$, and is independent of particle size since $\mathrm{k}_{\mathrm{m}}$ (rate constant film diffusion control) is inversely proportional to D (or R). 
For a multi-sized PSD, the particles of smaller diameter react faster than those with the larger sizes. Therefore, the fraction of unreacted (FU) particles will be also a function of the PSD, namely:

$F U=\int_{0}^{\infty}(f(D, t))(p(D)) d D$

with,

$$
\begin{aligned}
& f(D, t)=1-X_{B}=0, \quad 0<D<D_{t} \\
& f(D, t)=1-X_{B}=g(D, t), \quad D_{t}<D<D_{\text {max }}
\end{aligned}
$$

where

$\mathrm{p}(\mathrm{D})=$ particle size density function based on mass of particles;

$D_{\max }=$ the size density of the largest particle in the system;

$g(D, t)=$ the expression for $f(D, t)$ represented by (9), (10) and (11) for each control regime; and

$D_{t}=k_{r n} t$ (chemical reaction control), $D_{t}=\left(k_{d n} t\right)^{0,5}$ (inert/ash layer diffusion control), and $\mathrm{D}_{\mathrm{t}}=\mathrm{k}_{\mathrm{mn}} \mathrm{t}$ (liquid film diffusion control).

(13) and (14) imply that in a given time all particles with size less than a certain size $D_{t}$ are fully reacted $\left(X_{B}=1\right)$, whereas particles with size larger than $D_{t}$ are reacting following (14). Substituting (13) and (14) into (12) gives:

$F U=\int_{0}^{D t} 0(p(D)) d D+\int_{D_{t}}^{D_{\max }}(f(D, t))(p(D)) d D$

Therefore, the overall conversion or fraction reacted is given as

$X_{B}=1-\int_{D_{t}}^{D_{\max }}(f(D, t))(p(D)) d D$

The Rosin-Rammler PSD was applied in the current work.

\section{Experimental details}

\subsection{Sample preparation}

The sample utilized in the leaching experiments was a chalcopyrite chunk, which was crushed and then ground in an orbital mill. This sample was subjected to analysis in a laser particle size analyser, model Cilas 1064 and the average particle size was measured as $19.6 \mu \mathrm{m}$ (Fig. 1). X-ray diffraction (Shimadzu, model 6000) showed chalcopyrite as the main mineral phase along with traces of magnetite, pyrite and calcite. The content of copper, iron and sulphur was quantified by acid digestion followed by analysis in an ICP-OES (Varian,



Fig. 1. Particle size distribution of the chalcopyrite sample under study.
725), which revealed the presence of $30.6 \% \mathrm{Cu}, 28.2 \%$ Fe and $34.3 \% \mathrm{~S}$, indicating that chalcopyrite represented nearly $90 \%$ of the sample.

\subsection{Leaching tests}

The chemical leaching tests were performed batchwise, using a 500 - $\mathrm{mL}$ unbaffled $(7.5 \mathrm{~cm}$ diameter $\times 14 \mathrm{~cm}$ height) jacketed glass reactor. Temperature was controlled by circulating water heated by a thermostatic bath equipped with an external circulation pump. The glass reactor was magnetically stirred ( $3 \mathrm{~cm}$ bar) and a previous work using the same apparatus indicated that the film diffusion resistance was negligible above $720 \mathrm{~min}^{-1}$ (Porcaro, 2010) and then the value of $850 \mathrm{~min}^{-1}$ was selected for the present work. Leaching solutions were prepared from analytical grade chemicals (ferric sulphate, cupric sulphate, sulphuric acid and sodium chloride) and distilled water and the effect of chloride ions $(0 \mathrm{~mol} / \mathrm{L}$ to $2 \mathrm{~mol} / \mathrm{L}$ ) on chalcopyrite leaching was determined at $80^{\circ} \mathrm{C}$, using $1 \mathrm{~mol} / \mathrm{L}$ sulphuric acid and $1 \mathrm{~mol} / \mathrm{L}$ ferric sulphate. The influence of ferric iron $(0 \mathrm{~mol} / \mathrm{L}$ to $1 \mathrm{~mol} / \mathrm{L})$ was also assessed at $80{ }^{\circ} \mathrm{C}$, in the presence of $1 \mathrm{~mol} / \mathrm{L}$ sulphuric acid and $2 \mathrm{~mol} / \mathrm{L}$ sodium chloride. Similar conditions were utilized to analyse the effect of cupric sulphate $(0 \mathrm{~mol} / \mathrm{L}$ to $0.5 \mathrm{~mol} / \mathrm{L})$ on the leaching rate. Finally, temperature was varied from $70{ }^{\circ} \mathrm{C}$ to $90{ }^{\circ} \mathrm{C}$, in the experiments performed with $1 \mathrm{~mol} / \mathrm{L}$ sulphuric acid, $2 \mathrm{~mol} / \mathrm{L}$ sodium chloride and either $1 \mathrm{~mol} / \mathrm{L}$ ferric iron or $0.5 \mathrm{~mol} / \mathrm{L}$ cupric sulphate.

Throughout the experiments, a $0.1 \%(\mathrm{w} / \mathrm{v})$ solids concentration was utilized and $1.5 \mathrm{~mL}$ samples were collected regularly for chemical analysis (copper and iron), carried out in an ICP-OES (Varian, 725). In the experiments with ferric iron, copper concentrations were utilized to determine chalcopyrite dissolution, whereas iron concentrations were used with the same aim in the experiments with cupric sulphate and sodium chloride.

The morphological features of the chalcopyrite sample and reactions products formed in the current study were analysed by SEM-EDS. The solid particles were mounted in epoxy resin and then polished to a flat, mirrored surface. Samples were carbon coated afterwards and then examined in a VEGA 3LMH model from TESCAN. The leaching residue was filtered, washed with distilled water dried at room temperature and stored in a freezer to avoid or reduce oxidation until observation.

\section{Results and discussion}

\subsection{Effect of the type of leaching agent on chalcopyrite leaching}

Because of the reduced availability of freshwater in some countries, the mining industry is relying increasingly on seawater for mineral processing and hydrometallurgical operations. In this new industrial context mixed sulphate-chloride systems will have important implications on sulphide leaching and downstream processes. Mixed systems are also considered because they are less expensive than leaching in pure chloride systems. The positive impact of chloride ions on copper extraction in sulphate media is well known, but there is no agreement on what is the threshold value in which copper extraction stops to be benefited. Lu et al. (2000) and later Ruiz et al. (2011) suggested that sodium chloride significantly increases the leaching rate up to $0.5 \mathrm{~mol} / \mathrm{L}$ $\mathrm{NaCl}$ using oxygen as oxidant. Conversely, Palmer et al. (1981) reported a considerable increase in copper leaching from chalcopyrite up to 1 $\mathrm{mol} / \mathrm{L}$ chloride in $\mathrm{FeCl}_{3}-\mathrm{HCl}$ systems, whereas Yévenes et al. (2010b) observed no effect of chloride (0.2-2.0 mol/L) during an Eh-controlled leaching in experiment with the copper sulphide.

Whereas chloride is a prerequisite for the $\mathrm{Cu}^{2+} / \mathrm{Cu}^{+}$to be effective as the oxidant during leaching, it is not absolutely required in the case of the $\mathrm{Fe}^{3+} / \mathrm{Fe}^{2+}$, but it can catalyse chalcopyrite oxidation. Therefore, Fig. 2 shows copper extractions as a function of time for concentrations of chloride ions up to $2.0 \mathrm{~mol} / \mathrm{L}$ in the presence of both $1 \mathrm{~mol} / \mathrm{L} \mathrm{Fe}^{3+}$ and $1 \mathrm{~mol} / \mathrm{L} \mathrm{H}_{2} \mathrm{SO}_{4}$. Copper dissolution increased from $5 \%$ in the absence to 




Fig. 2. Effect of concentration of $\mathrm{NaCl}$ on chalcopyrite dissolution. $1.0 \mathrm{~mol} / \mathrm{L} \mathrm{H}_{2} \mathrm{SO}_{4}$, $1.0 \mathrm{~mol} / \mathrm{L} \mathrm{Fe}^{3+}$ and $80^{\circ} \mathrm{C}$. PSD following the Rosin-Rammler distribution $(\mu=19.6 \mu \mathrm{m}$ and $\mathrm{CV}=0.83)$.

$22 \%$ with $1.5 \mathrm{~mol} / \mathrm{L} \mathrm{NaCl}$, within three hours, confirming the positive effect of chloride ions on chalcopyrite leaching by ferric iron. Such an improvement was reduced at higher chloride concentrations because the final extraction marginally increased to $24 \%$ when the $\mathrm{NaCl}$ concentration was increased further to $2.0 \mathrm{~mol} / \mathrm{L}$. Notwithstanding, $2.0 \mathrm{~mol} / \mathrm{L}$ $\mathrm{NaCl}$ solutions were utilized throughout the kinetic study to ensure that chloride concentrations did not limit metal extraction. Such results are consistent with the work of Carneiro and Leão (2007), who also observed a significant increase in copper extraction by ferric iron with chloride concentrations of up to $1.5 \mathrm{~mol} / \mathrm{L}$ chloride in the first $3 \mathrm{~h}$ of experiment.

The effect of the leaching agent $\left(\mathrm{Fe}^{3+}\right.$ or $\left.\mathrm{Cu}^{2+}\right)$ on chalcopyrite leaching is seen in Fig. 3, which depicts metal extractions from chalcopyrite at different concentrations of both ferric- (a) and cupric ions (b). Chalcopyrite dissolution was assessed from copper concentrations in the experiments with ferric iron, whereas iron concentration was applied with the same purpose in the experiments with $\mathrm{CuSO}_{4}$. A 15\%-copper extraction was observed in the absence of ferric iron, whereas the same parameter increased with the ferric iron concentration up to $0.5 \mathrm{~mol} / \mathrm{L} \mathrm{Fe}^{3+}$, attaining $24 \%$, but no further increase was observed for $1.0 \mathrm{~mol} / \mathrm{L} \mathrm{Fe}^{3+}$ (Fig. 3(a)). Unlike Córdoba et al. (2008a), who proposed that no further improvement in copper extraction from chalcopyrite was observed for initial ferric iron concentrations above $0.01 \mathrm{~mol} / \mathrm{L}$ $\mathrm{Fe}^{3+}$, the findings of the present work suggest such this threshold was increased to $0.5 \mathrm{~mol} / \mathrm{L}$ when chloride was present in the system.

Chalcopyrite dissolution reached $46 \%$ with $0.5 \mathrm{~mol} / \mathrm{L} \mathrm{Cu}^{2+}$ and $2.0 \mathrm{~mol} / \mathrm{L} \mathrm{NaCl}$ (Fig. 3(b)), in a three-hour experiment with $\mathrm{CuSO}_{4^{-}}$ $\mathrm{NaCl}$. That implies in dissolution yields twice as high as that observed with ferric iron. However, chalcopyrite dissolution in experiments with $0.125 \mathrm{~mol} / \mathrm{L}$ and $0.25 \mathrm{~mol} / \mathrm{L} \mathrm{CuSO}_{4}$ were similar. Even though a slight tendency of increased dissolution in the beginning of tests can be noticed, the experimental errors (errors bar) does not enable to be assertive. In addition, Yévenes et al. (2010a) reported no effect of the $\mathrm{Cu}^{2+}$ concentration on chalcopyrite leaching with chloride, but stressed that a small amount of cupric ions $(1.6 \mathrm{mmol} / \mathrm{L})$ catalysed the leaching of the copper sulphide.

It appears from Fig. 3 that the rate of chalcopyrite dissolution did not strongly vary with the concentration of the oxidizing agent. Nevertheless, chalcopyrite oxidation by cupric ions was remarkably more effective than that achieved with ferric sulphate in mixed sodium chloride-sulphuric acid solutions. Such an outcome is ascribed to a faster and more reversible $\mathrm{Cu}^{2+}$ reduction to $\mathrm{Cu}^{+}$(on the chalcopyrite surface) as compared to that of the $\mathrm{Fe}^{3+} / \mathrm{Fe}^{2+}$ couple (Dutrizac, 1992).

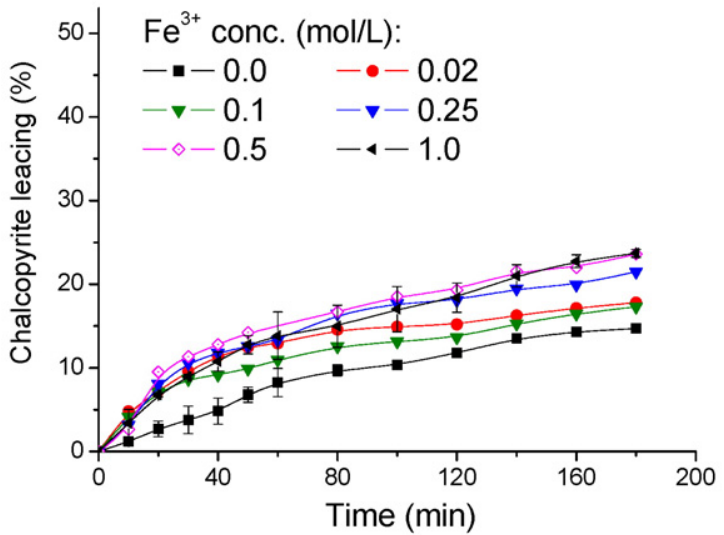

(a)



(b)

Fig. 3. Effect of $\mathrm{Fe}^{3+}$ (a) and $\mathrm{Cu}^{2+}$ (b) concentrations on chalcopyrite dissolution at $1.0 \mathrm{~mol} / \mathrm{L} \mathrm{H}_{2} \mathrm{SO}_{4}, 2.0 \mathrm{~mol} / \mathrm{L} \mathrm{NaCl}$ and $80{ }^{\circ} \mathrm{C}$. PSD following the Rosin-Rammler distribution $(\mu=19.6 \mu \mathrm{m}$ and $\mathrm{CV}=0.83)$.

\subsection{Effect of temperature on the leaching of chalcopyrite}

Temperature is an important parameter in the dissolution of copper sulphides and both faster leaching kinetics and larger extraction yields are expected when it is increased. Fig. 4(a) presents chalcopyrite leaching as a function of time for a solution containing $1.0 \mathrm{~mol} / \mathrm{L} \mathrm{Fe}^{3+}$, $1.0 \mathrm{~mol} / \mathrm{L} \mathrm{H}_{2} \mathrm{SO}_{4}$ and $2.0 \mathrm{~mol} / \mathrm{L} \mathrm{NaCl}$, whereas Fig. 4(b) shows the same results for the $\mathrm{Cu}^{2+} / \mathrm{Cu}^{1+}$ couple at $0.5 \mathrm{~mol} / \mathrm{L}$ cupric ions, $1.0 \mathrm{~mol} / \mathrm{L} \mathrm{H}_{2} \mathrm{SO}_{4}$ and $2.0 \mathrm{~mol} / \mathrm{L} \mathrm{NaCl}$. In both cases the range investigated was from $70{ }^{\circ} \mathrm{C}$ to $90{ }^{\circ} \mathrm{C}$ in $5{ }^{\circ} \mathrm{C}$ steps.

Copper extraction increased from $17 \%$ to $50 \%$ as the temperature also increased from $70{ }^{\circ} \mathrm{C}$ to $90{ }^{\circ} \mathrm{C}$, respectively, in the presence of $1.0 \mathrm{~mol} / \mathrm{L} \mathrm{Fe}^{3+}, 1.0 \mathrm{~mol} / \mathrm{L} \mathrm{H}_{2} \mathrm{SO}_{4}$ and $2.0 \mathrm{~mol} / \mathrm{L} \mathrm{NaCl}$ (Fig. 4(a)). With cupric ions (Fig. 4 (b)), the same parameter increased from $35 \%$ to $70 \%$, in three hours of experiment. Such results emphasize the dependence of chalcopyrite dissolution on temperature, in addition to the chloride concentration. As stated, chalcopyrite dissolution was higher when leaching was carried out with cupric ions. Nonetheless, the performance of both oxidants with regard to metal extraction approached each other at higher temperatures, i.e. chalcopyrite dissolution in tests with cupric ions was nearly twice as high as that achieved with ferric ions up to $80^{\circ} \mathrm{C}$, but it is only 1.4 times larger at $85^{\circ} \mathrm{C}$ and $90^{\circ} \mathrm{C}$. The effect of temperature on dissolution chalcopyrite has been extensively studied and the results vary quite substantially depending on the oxidant and the temperature range investigated. Yévenes et al. (2010a) reported copper extractions improving from $10 \%$ to $80 \%$ within $800 \mathrm{~h}$ when the 

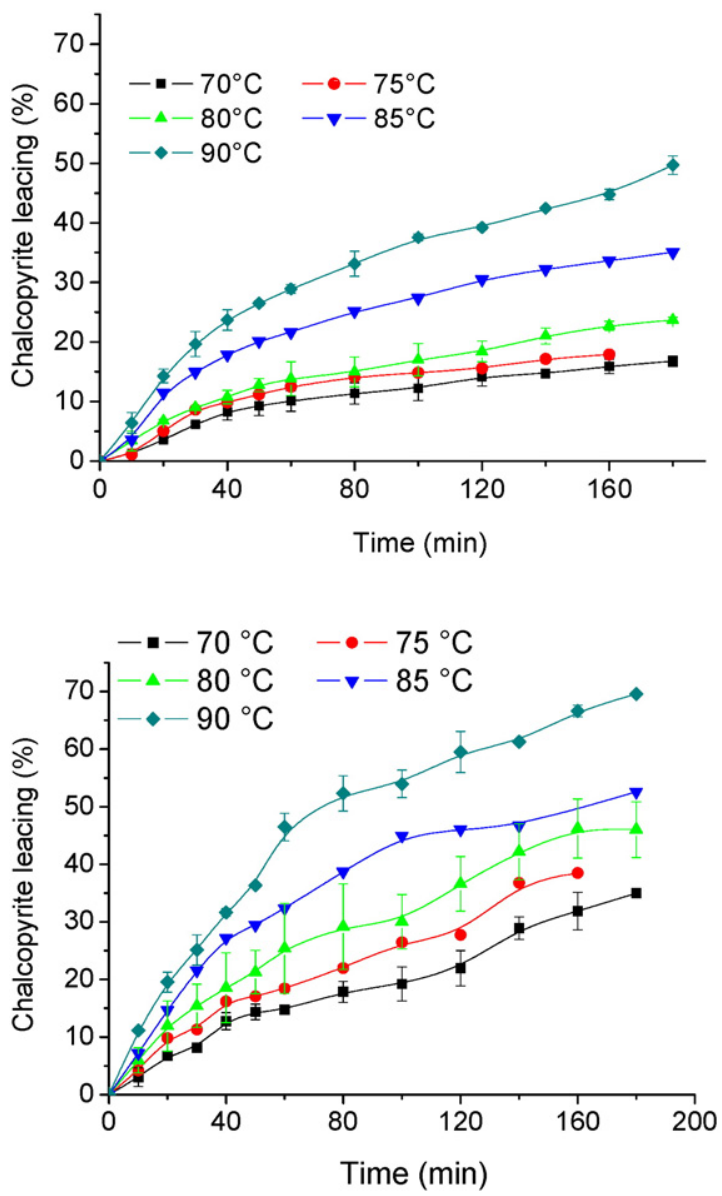

Fig. 4. Effect of temperature on chalcopyrite dissolution: (a) $1.0 \mathrm{~mol} / \mathrm{L} \mathrm{Fe}^{3+}$ and (b) $0.5 \mathrm{~mol} / \mathrm{L} \mathrm{Cu}^{2+} .1 .0 \mathrm{~mol} / \mathrm{L} \mathrm{H}_{2} \mathrm{SO}_{4}, 2.0 \mathrm{~mol} / \mathrm{L} \mathrm{NaCl}$. The PSD followed the RosinRammler distribution $(\mu=19.6 \mu \mathrm{m}$ and $\mathrm{CV}=0.83)$.

temperature was varied from $25^{\circ} \mathrm{C}$ to $50{ }^{\circ} \mathrm{C}$ in the presence of $0.2 \mathrm{~mol} / \mathrm{L}$ $\mathrm{HCl}, 7.8 \mathrm{mmol} / \mathrm{L} \mathrm{Cu}^{2+}$ and at constant potential $(580 \mathrm{mV}-\mathrm{Ag} / \mathrm{AgCl})$. Similarly, Lu et al. (2000) described an increase in leaching yield from approximately $30 \%$ to $95 \%$ in a 9-hour test when the temperature was varied from $60{ }^{\circ} \mathrm{C}$ to $95{ }^{\circ} \mathrm{C}$. In addition, Bonan et al. (1981) observed a tenfold elevation ( $5 \%$ to $50 \%$ ) in copper extraction by changing the temperature from $75{ }^{\circ} \mathrm{C}$ to $95{ }^{\circ} \mathrm{C}$ over a period of three hours, using cupric ions as oxidant in a degassed hydrochloric acid medium $(0.1 \mathrm{~mol} / \mathrm{L}$ $\mathrm{HCl}$ and $3 \mathrm{~mol} / \mathrm{L} \mathrm{NaCl}$ ).

\subsection{Kinetics of chalcopyrite leaching}

From data presented in Fig. 4, the kinetics parameters related to chalcopyrite leaching were determined by applying the shrinking core model. This model was selected because it is widely applied in leaching systems in general and sulphide dissolution, in particular. It is usually assumed that either an elemental sulphur layer and/or metal-deficient sulphide acts as a barrier (ash layer) for the diffusion of the reagent (Majuste et al., 2012; Souza et al., 2007; Warren et al., 1982; Yévenes et al., 2010b). Fig. 5 shows SEM-EDS images of a partially reacted chalcopyrite particle (point 1 ) surrounded by a layer of elemental sulphur (points 2, 3 and 4) as confirmed by the EDS analysis in each point, and this is consistent with (13) and (14). The presence of elemental sulphur was also observed in the $\mathrm{x}$-ray diffraction of the leaching residues. In addition to elemental sulphur, other products of chalcopyrite dissolution have been suggested, but advanced characterization techniques are needed to detect such phases (Majuste et al., 2012). Regardless of the nature of the inert layer, the shrinking core model for particles of constant size was applied to model the leaching kinetics.

As stated, the classical form of the SCM is valid solely for reacting particles of the same size (monosize PSD), which was not the case in the current work. Therefore, the mathematical approach developed by Gbor and Jia (2004) was selected and included in the current kinetics analysis.

In terms of particle size distributions, the Rosin-Rammler function ((17)) (Sohn and Wadsworth, 1979) was chosen to represent the PSD in the current work because it revealed the best fitting to the experimental data.

$p(D)=\frac{m}{l^{m}} D^{m-1} \exp \left[-\left(\frac{D}{l}\right)^{m}\right]$

In (17), $p(D)$ is the particle size density function based on mass of particles, $D$ is the particle diameter, whereas $m$ and $l$ are positive constants. This function has the following expressions for its mean $(\mu)$ and covariance (CV), where $\Gamma$ is the gamma function (Sohn and Wadsworth, 1979):

$\mu=l . \Gamma\left(\frac{m+1}{m}\right)$

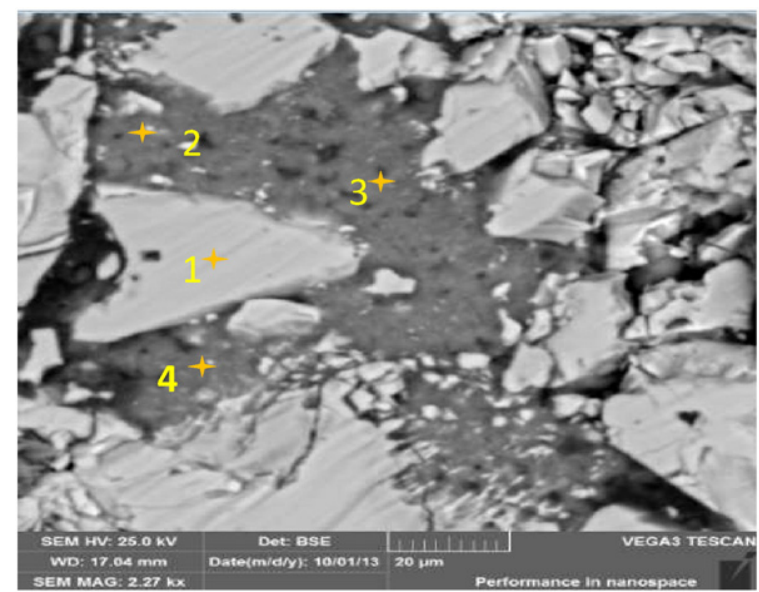

\begin{tabular}{cccc}
\hline spot & $\mathrm{Cu}(\%)$ & $\mathrm{Fe}(\%)$ & $\mathrm{S}(\%)$ \\
\hline 1 & 35.7 & 30.0 & 34.3 \\
2 & 5.0 & 5.6 & 89.4 \\
3 & - & - & 100 \\
4 & - & 91.7 & 8.3 \\
C.T.* & 34.62 & 30.43 & 34.94 \\
\hline & * theoretical chalcopyrite composition
\end{tabular}

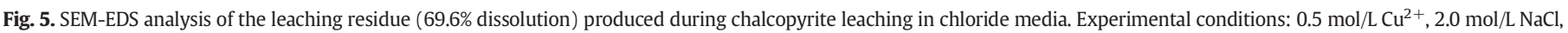
$1.0 \mathrm{~mol} / \mathrm{L} \mathrm{H}_{2} \mathrm{SO}_{4}, 90{ }^{\circ} \mathrm{C}$. 
$C V=\frac{\left[\Gamma\left(\frac{m+2}{m}\right)-\Gamma^{2}\left(\frac{m+1}{m}\right)\right]^{1 / 2}}{\Gamma\left(\frac{m+1}{m}\right)}$

The cumulative Rosin-Rammler distribution (F) can be represented as follows:

$F(D)=1-\exp \left[-\left(\frac{D}{l}\right)^{m}\right]$

Substituting (9) and (17) into (16) gives:

$X_{B}=1-\int_{D t}^{D_{\max }}\left(1-\frac{k_{r n} t}{D}\right)^{3} \cdot \frac{m}{l^{m}} D^{m-1} \exp \left[-\left(\frac{D}{l}\right)^{m}\right] d D$

$D_{\max }$ corresponds to the value for which:

$\int_{0}^{D_{\max }}\left(1-\frac{k_{r n} t}{D}\right)^{3} \cdot \frac{m}{l^{m}} D^{m-1} \exp \left[-\left(\frac{D}{l}\right)^{m}\right] d D \geq 0.999$

The effect of the PSD on the kinetics parameters can be related to the covariance (CV) of the distribution. According to Gbor and Jia (2004), incorporating the particle size distribution into the shrinking core model is not required when the particle size distribution has a CV $<0.3$. However, the PSD can affect the interpretation of the kinetics mechanisms at large CV values. For instance, Gbor and Jia (2004) reported a very good fit $\left(r^{2}=0.997\right)$ to the equation representing diffusion in the ash layer (for particles of the same size) as the slowest step ((23)) for $\mathrm{CV}=0.9, \mathrm{k}_{\mathrm{rn}}=0.1 \mu \mathrm{m} / \mathrm{min}$ and a mean particle size of $100 \mu \mathrm{m}$ even though the process was actually chemically controlled (with a high activation energy).

$1-3\left(1-X_{B}\right)^{2 / 3}+2\left(1-X_{B}\right)=K_{D . t} \quad($ ash layer control $)$

The cumulative PSD of the chalcopyrite particles depicted in Fig. 1 was fitted to (20), which described well (SSE $=0.0197$ ) the experimental PSD used in the current work and produced optima values for $l$ and $m$ so that $\mu((18))$ and $C V((19))$ were calculated as $19.64 \mu \mathrm{m}$ and 0.83 , respectively. Because of this high CV value, the equation representing diffusion in the ash layer for particles of the same size ((23)) fitted very well $\left(r^{2}=0.98\right)$ with time $(t)$, whereas the expression $1-\left(1-X_{B}\right)^{1 / 3}$ (chemical control and monosize particles) did not produce a linear relationship with the experimental data. The application of (23) to leaching data produced at different temperatures enabled to determine the rate constants $\left(K_{D}\right)$ and subsequently the activation energy was calculated using the Arrhenius equation. The outcome was $122.3 \mathrm{~kJ} / \mathrm{mol}$ for experiments with $1.0 \mathrm{~mol} / \mathrm{L} \mathrm{Fe}^{3+}$ and $92.9 \mathrm{~kJ} / \mathrm{mol}$, for $0.5 \mathrm{~mol} / \mathrm{L}$ of $\mathrm{Cu}^{2+}$ ions. However, such values were not consistent with a diffusion-controlled aqueous processes (in which Ea is expected to be below $20 \mathrm{~kJ} / \mathrm{mol}$ ) (Levenspiel, 1999). Therefore, it was hypothesised that the observed linear relationship with (23) was a consequence of the broad PSD utilized in the current work rather than a process controlled by diffusion in the ash-layer, similarly to the findings of Gbor and Jia (2004).

Such a hypothesis was confirmed with a computer program written in mathematica 9.0 to solve (21) and a value for $\mathrm{k}_{\mathrm{rn}}(\mathrm{f}(\mathrm{D}, \mathrm{t}))$ was produced by minimizing the error given by the experimental and modelpredicted values of $\mathrm{X}_{\mathrm{B}}((24))$ :

Error $=\sum_{1}^{n p}\left(X_{B_{\text {exp }}}-X_{B_{\text {pred }}}\right)^{2}$

where $n p$ is the number of data points (fraction reacted) and subscripts "exp" and "pred" referrers to experimental and predicted values. Experimental data and the best curves are depicted in Fig. 6, whereas the rate constant $\left(\mathrm{k}_{\mathrm{rn}}\right)$ and the sum of squared errors (SSE) are

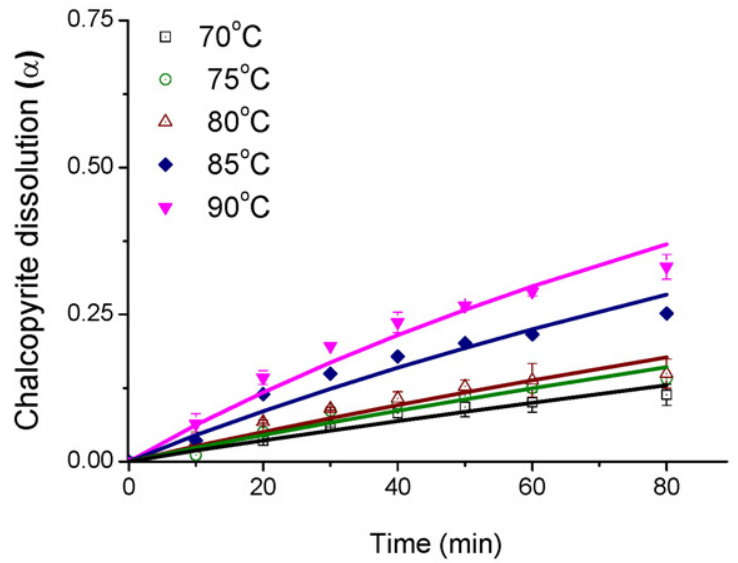

(a)

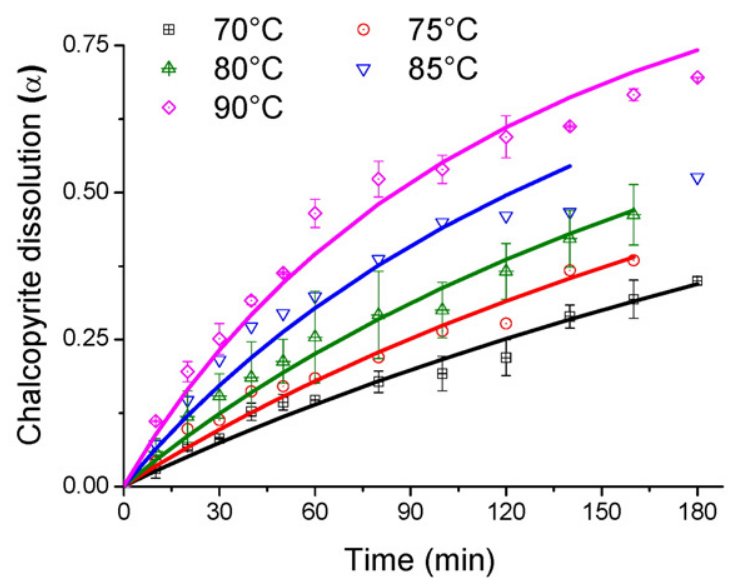

(b)

Fig. 6. Fitting of experimental data to the PSD-incorporated SCM model (chemical control) a different temperatures. Experimental conditions: $1.0 \mathrm{~mol} / \mathrm{L} \mathrm{Fe}^{3+}$ (a) and $0.5 \mathrm{~mol} / \mathrm{L} \mathrm{Cu}^{2+}$ (b) in the presence of $1.0 \mathrm{~mol} / \mathrm{L} \mathrm{H}_{2} \mathrm{SO}_{4}$ and $2.0 \mathrm{~mol} / \mathrm{L} \mathrm{NaCl}$. The PSD followed the RosinRammler distribution $(\mu=19.6 \mu \mathrm{m}$ and $\mathrm{CV}=0.83$ ).

presented in Table 1, suggesting that (21) describes the experimental values fairly well. As expected, the rate constant values were larger (50\% in average) in the experiments with the $\mathrm{Cu}^{2+} / \mathrm{Cu}^{1+}$ as compared to the $\mathrm{Fe}^{3+} / \mathrm{Fe}^{2+}$ couple and were justified by the faster discharge of $\mathrm{Cu}^{2+}$ ions on the chalcopyrite surface (Dutrizac, 1992).

The activation energies were calculated from the values of $k_{r n}$ achieved at each temperature and the Arrhenius plot is shown in Fig. 7. According to Fig. 7, the values of Ea were similar in both systems i.e. $66.6 \mathrm{~kJ} / \mathrm{mol}$ for $0.5 \mathrm{~mol} / \mathrm{L}$ of $\mathrm{Cu}^{2+}$ and $66.8 \mathrm{~kJ} / \mathrm{mol}$ with $1.0 \mathrm{~mol} / \mathrm{L}$ $\mathrm{Fe}^{3+}$, which confirms the chemical reaction as the rate-determining step, as previously suspected. Activation energy values ranging from $38 \mathrm{~kJ} / \mathrm{mol}$ to $130 \mathrm{~kJ} / \mathrm{mol}$ are reported for ferric iron leaching in the

Table 1

Values of Krn at different temperatures achieved during chalcopyrite leaching by either $\mathrm{Fe}^{3+} / \mathrm{Fe}^{2+}$ or $\mathrm{Cu}^{2+} / \mathrm{Cu}^{+}$couples. Experimental conditions: $1.0 \mathrm{~mol} / \mathrm{L} \mathrm{Fe}^{3+}$ and 0.5 $\mathrm{mol} / \mathrm{L} \mathrm{Cu}^{2+}$ in the presence of $1.0 \mathrm{~mol} / \mathrm{L} \mathrm{H}_{2} \mathrm{SO}_{4}$ and $2.0 \mathrm{~mol} / \mathrm{L} \mathrm{NaCl}$. The PSD followed the Rosin-Rammler distribution $(\mu=19.6 \mu \mathrm{m}$ and $\mathrm{CV}=0.83)$.

\begin{tabular}{llllll}
\hline Temperature $\left({ }^{\circ} \mathrm{C}\right)$ & \multicolumn{2}{l}{$\mathrm{Cu}^{2+} / \mathrm{Cu}^{+}$} & & \multicolumn{2}{l}{$\mathrm{Fe}^{3+} / \mathrm{Fe}^{2+}$} \\
\cline { 2 - 3 } & $\mathrm{Krn}$ & & & $\mathrm{Krn}$ & SSE \\
\hline 70 & 0.0149 & 0.0036 & & 0.0103 & 0.0006 \\
75 & 0.0199 & 0.0047 & & 0.0131 & 0.0011 \\
80 & 0.0262 & 0.0060 & & 0.0147 & 0.0016 \\
85 & 0.0379 & 0.0143 & & 0.0261 & 0.0031 \\
90 & 0.0542 & 0.0158 & & 0.0370 & 0.0035
\end{tabular}






Fig. 7. Arrhenius plot for the $\mathrm{Fe}^{3+}-\mathrm{Cl}$ and $\mathrm{Cu}^{2+}-\mathrm{Cl}$ leaching of chalcopyrite. Experimental conditions: $1.0 \mathrm{~mol} / \mathrm{L} \mathrm{Fe}^{3+}$ (a) and $0.5 \mathrm{~mol} / \mathrm{L} \mathrm{Cu}^{2+}$ (b) in the presence of $1.0 \mathrm{~mol} / \mathrm{L} \mathrm{H}_{2} \mathrm{SO}_{4}$ (b) and $2.0 \mathrm{~mol} / \mathrm{L} \mathrm{NaCl}$. The PSD followed the Rosin-Rammler distribution $(\mu=19.6 \mu \mathrm{m}$ and $\mathrm{CV}=0.83$ )

$35^{\circ} \mathrm{C}-100{ }^{\circ} \mathrm{C}$ temperature range (Córdoba et al., 2008a; Dutrizac, 1981). Particularly in ferric chloride medium values from $1.1 \mathrm{~kJ} / \mathrm{mol}$ to $87 \mathrm{~kJ} /$ mol are reported for temperatures between $3.5{ }^{\circ} \mathrm{C}$ and $110{ }^{\circ} \mathrm{C}(\mathrm{Al}-$ Harahsheh et al., 2008). Conversely, leaching with both copper and chloride ions (from $60{ }^{\circ} \mathrm{C}$ to $105^{\circ} \mathrm{C}$ ) produced activation energies from $59.5 \mathrm{~kJ} / \mathrm{mol}$ to $134.7 \mathrm{~kJ} / \mathrm{mol}$ (Bonan et al., 1981; Hirato et al., 1987). Thus, the values reported herein are consistent with the previous published figures. Furthermore, the similar Ea values observed in both processes imply that temperature affects both leaching rates equally, although the copper leaching kinetics in the $\mathrm{Cu}^{2+}-\mathrm{Cl}^{-}$system is intrinsically faster (larger Krn values), Table 1.

The activation energy encountered in the current work with cupric ions, $66.6 \mathrm{~kJ} / \mathrm{mol}$, is similar to that reported by Yévenes et al. (2010a) despite the different experimental conditions in both investigations. The authors determined a Ea value of $72-73 \mathrm{~kJ} / \mathrm{mol}$, for two different chalcopyrite concentrates and also proposed chemical reaction as the rate-determining step (Yévenes et al., 2010a). Likewise, Ruiz et al. (2011) estimated an activation energy of $91.2 \mathrm{~kJ} / \mathrm{mol}$ in the $80{ }^{\circ} \mathrm{C}-$ $100{ }^{\circ} \mathrm{C}$ temperature range.

Despite all issues related to corrosion of pipes and reactors, the presence of chloride ions largely improves chalcopyrite leaching. Even in a bioleaching context, it can have beneficial effects on copper extraction because some chloride tolerant bacterial strains have been recently isolated. The current work shows that in either system $\left(\mathrm{Fe}^{3+}-\mathrm{Cl}^{-}\right.$or $\mathrm{Cu}^{2+}-\mathrm{Cl}^{-}$) the leaching kinetics is chemically controlled, confirming the positive effect of high temperatures on both leaching and bioleaching of chalcopyrite ores and concentrates.

\section{Conclusions}

As suggested by the high values of activation energy, chalcopyrite leaching with chloride ions is highly temperature dependent, with faster kinetics in $\mathrm{Cu}^{2+}-\mathrm{Cl}^{-}$media as compared to $\mathrm{Fe}^{3+}-\mathrm{Cl}^{-}$solutions (rate constants 1.5 times larger). Moreover, copper extraction was also higher (50\%) with cupric ions. Incorporating particle size distribution in the SCM was required and enabled to determine an activation energy value which is consistent with the kinetic regime proposed. Temperature seems to affect both leaching systems $\left(\mathrm{Fe}^{3+}\right.$ and $\left.\mathrm{Cu}^{2+}\right)$ similarly with activation energies of $66 \mathrm{~kJ} / \mathrm{mol}$ in both cases.

\section{Acknowledgements}

The financial support from the funding agencies FINEP, FAPEMIG, CNPq and CAPES as well as UFOP and REDEMAT are gratefully appreciated. The CAPES and CNPq scholarships to the authors are particularly acknowledged.

\section{References}

Al-Harahsheh, M., Kingman, S., Al-Harahsheh, A., 2008. Ferric chloride leaching of chalcopyrite: synergetic effect of $\mathrm{CuCl}_{2}$. Hydrometallurgy 91, 89-97.

Antonijević, M.M., Janković, Z.D., Dimitrijević, M.D., 2004. Kinetics of chalcopyrite dissolution by hydrogen peroxide in sulphuric acid. Hydrometallurgy 71, 329-334.

Baba, A., Ayinla, K., Adekola, F., Bale, R., Ghosh, M., Alabi, A.F., Sheik, A., Folorunso, I., 2013. Hydrometallurgical application for treating a Nigerian chalcopyrite ore in chloride medium: part I. dissolution kinetics assessment. Int. J. Miner. Metall. Mater. 20, 1021-1028.

Bonan, M., Demarthe, J.M., Renon, H., Baratin, F., 1981. Chalcopyrite leaching by $\mathrm{CuCl}_{2}$ in strong NaCl solutions. Metall. Trans. B 12, 269-274.

Cai, Y., Chen, X., Ding, J., Zhou, D., 2012. Leaching mechanism for chalcopyrite in hydrochloric acid. Hydrometallurgy 113-114, 109-118.

Carneiro, M.F.C., Leão, V.A., 2007. The role of sodium chloride on surface properties of chalcopyrite leached with ferric sulphate. Hydrometallurgy 87, 73-82.

Córdoba, E.M., Muñoz, J.A., Blázquez, M.L., González, F., Ballester, A., 2008a. Leaching of chalcopyrite with ferric ion. Part I: General aspects. Hydrometallurgy 93, 81-87.

Córdoba, E.M., Muñoz, J.A., Blázquez, M.L., González, F., Ballester, A., 2008b. Leaching of chalcopyrite with ferric ion. Part III: Effect of redox potential on the silver-catalyzed process. Hydrometallurgy 93, 97-105.

Córdoba, E.M., Muñoz, J.A., Blázquez, M.L., González, F., Ballester, A., 2008c. Leaching of chalcopyrite with ferric ion. Part IV: The role of redox potential in the presence of mesophilic and thermophilic bacteria. Hydrometallurgy 93, 106-115.

Dutrizac, J.E., 1978. The kinetics of dissolution of chalcopyrite in ferric ion media. Metall. Trans. B 9, 431-439.

Dutrizac, J.E., 1981. The dissolution of chalcopyrite in ferric sulfate and ferric chloride media. Metall. Trans. B 12, 371-378.

Dutrizac, J.E., 1992. The leaching of sulphide minerals in chloride media. Hydrometallurgy 29, 1-45.

Gbor, P.K., Jia, C.Q., 2004. Critical evaluation of coupling particle size distribution with the shrinking core model. Chem. Eng. Sci. 59, 1979-1987.

Hackl, R.P., Dreisinger, D.B., Peters, E., King, J.A., 1995. Passivation of chalcopyrite during oxidative leaching in sulfate media. Hydrometallurgy 39, 25-48.

Havlík, T., Kammel, R., 1995. Leaching of chalcopyrite with acidified ferric chloride and carbon tetrachloride addition. Miner. Eng. 8, 1125-1134.

Hirato, T., Majima, H., Awakura, Y., 1987. The leaching of chalcopyrite with cupric chloride. Metall. Trans. B 18, 31-39.

Kaplun, K., Li, J., Kawashima, N., Gerson, A.R., 2011. Cu and Fe chalcopyrite leach activation energies and the effect of added $\mathrm{Fe}^{3+}$. Geochim. Cosmochim. Acta 75, 5865-5878.

Levenspiel, O., 1999. Chemical reaction engineering. Ind. Eng. Chem. Res. 38, 4140-4143.

Lu, Z.Y., Jeffrey, M.I., Lawson, F., 2000. The effect of chloride ions on the dissolution of chalcopyrite in acidic solutions. Hydrometallurgy 56, 189-202.

Lundström, M., Aromaa, J., Forsén, O., Hyvärinen, O., Barker, M.H., 2005. Leaching of chalcopyrite in cupric chloride solution. Hydrometallurgy 77, 89-95.

Majima, H., Awakura, Y., Hirato, T., Tanaka, T., 1985. The leaching of chalcopyrite in ferric chloride and ferric sulfate solutions. Can. Metall. Q. 24, 283-291.

Majuste, D., Ciminelli, V.S.T., Osseo-Asare, K., Dantas, M.S.S., Magalhaes-Paniago, R., 2012. Electrochemical dissolution of chalcopyrite: detection of bornite by synchrotron small angle X-ray diffraction and its correlation with the hindered dissolution process. Hydrometallurgy 111-112, 114-123.

Murhammer, D., Davis, D., Levenspiel, O., 1986. Shringking core model/reaction control for a wide size distribution of solids. Chem. Eng. J. 32, 87-91.

Nicol, M., Miki, H., Velásquez-Yévenes, L., 2010. The dissolution of chalcopyrite in chloride solutions: part 3. Mechanisms. Hydrometallurgy 103, 86-95.

Nicol, M.J., Rautenbach, G.F., Van, B.C., 2012. A Chloride Method for Bioleaching, International Application Published Under the Patent Cooperation Treaty (PCT).

Ohtsuka, N., Mitarai, T., 2008. Method of Leaching Copper Sulfide Ores Containing Chalcopyrite. Patent Application Publication, United States.

Padilla, R., Letelier, H., Ruiz, M.C., 2013. Kinetics of copper dissolution in the purification of molybdenite concentrates by sulfidation and leaching. Hydrometallurgy 137, 78-83.

Palmer, B.R., Nebo, C.O., Rau, M.F., Fuerstenau, M.C., 1981. Rate phenomena involved in the dissolution of chalcopyrite in chloride bearing lixiviants. Metall. Trans. B 12, 595-601.

Porcaro, R.R., 2010. In: Preto, U.F.d.O. (Ed.), Estudos cinéticos de lixiviação de calcopirita. Escola de Minas, Ouro Preto, p. 62.

Rautenbach, G.F., Davis-Belmar, C.S., Demergasso, C.S., 2011. Method of Treating a Sulphide Mineral. Patent Application Publication, United States.

Ruiz, M.C., Montes, K.S., Padilla, R., 2011. Chalcopyrite leaching in sulfate chloride media at ambient pressure. Hydrometallurgy 109, 37-42

Sahu, S.K., Asselin, E., 2011. Characterization of residue generated during medium temperature leaching of chalcopyrite concentrate under CESL conditions. Hydrometallurgy $110,107-114$

Sohn, H.Y., Wadsworth, M.E., 1979. Rate Processes of Extractive Metallurgy. 1 Ed. Plenum Press, New York.

Souza, A.D., Pina, P.S., Leão, V.A., Silva, C.A., Siqueira, P.F., 2007. The leaching kinetics of a zinc sulphide concentrate in acid ferric sulphate. Hydrometallurgy 89, 72-81.

Torres, C.M., Taboada, M.E., Graber, T.A., Herreros, O.O., Ghorbani, Y., Watling, H.R., 2015. The effect of seawater based media on copper dissolution from low-grade copper ore. Miner. Eng. 71, 139-145. 
Warren, G.W., Wadsworth, M.E., El-Raghy, S.M., 1982. Passive and transpassive anodic behavior of chalcopyrite in acid solutions. Metall. Mater. Trans. B Process Metall. Mater. Process. Sci. 13, 571-579.

Watling, H.R., 2013. Chalcopyrite hydrometallurgy at atmospheric pressure: 1. review of acidic sulfate, sulfate chloride and sulfate nitrate process options. Hydrometallurgy 140, 163-180.

Watling, H.R., 2014. Chalcopyrite hydrometallurgy at atmospheric pressure: 2. review of acidic chloride process options. Hydrometallurgy 146, 96-110.
Yévenes, L.V., Miki, H., Nicol, M., 2010a. The dissolution of chalcopyrite in chloride solutions: part 2: effect of various parameters on the rate. Hydrometallurgy 103, 80-85. Yévenes, L.V., Nicol, M., Miki, H., 2010b. The dissolution of chalcopyrite in chloride solutions: Part 1. The effect of solution potential. Hydrometallurgy 103, 108-113.

Yoo, K., Kim, S.-k., Lee, J.-c., Ito, M., Tsunekawa, M., Hiroyoshi, N., 2010. Effect of chloride ions on leaching rate of chalcopyrite. Miner. Eng. 23, 471-477. 